Int. J. Electrochem. Sci., 16 (2021) Article ID: 210646

International Journal of

ELECTROCHEMICAL

SCIENCE

www.electrochemsci.org

\title{
Corrosion Protection of Copper Foil by Ni-W Electrodeposited Coating in Kaolin Slurry
}

\author{
Chien-Hung Lin*, Pei-Jing Teng \\ Department of Physics, ROC Military Academy, Feng-Shan, Kaohsiung 830, Taiwan \\ *E-mail: linhungcma@gmail.com
}

doi: $10.20964 / 2021.06 .12$

Received: 4 April 2020 / Accepted: 1 April 2021 / Published: 30 April 2021

\begin{abstract}
The electrodeposited $\mathrm{Ni}-\mathrm{W}$ layer was coated on a $\mathrm{Cu}$ substrate, and the plating bath was treated with a nickel sulphate solution. The corrosion resistance of the coating layer was evaluated using a corrodkote test with 1-20 repetitive cycles, and the SSRT (slow strain rate test) was employed to characterize the mechanical properties of the Ni-W layer on the $\mathrm{Cu}$ substrate. In the ambient atmosphere, the tensile strength of the $\mathrm{Cu}$ substrate with and without Ni-W coating were $285 \mathrm{MPa}$ and $240 \mathrm{MPa}$, respectively. Moreover, the strength of Ni-W coating was gradually reduced to the minimum value (250 MPa) over 20 cycles in the corrodkote environment. The fracture surface was observed by scanning electron microscopy (SEM), and the Ni-W coating demonstrated ductile-type fracture and partial brittle cleavage due to its quasi-cleavage features. As the potentiodynamic polarization, the corrosion current densities of the bare $\mathrm{Cu}$ with and without $\mathrm{Ni}-\mathrm{W}$ coating in the presence of the corrodkote environment were 8.97 $\times 10^{-6}$ and $1.84 \times 10^{-4} \mathrm{~A} / \mathrm{cm}^{2}$, respectively. Hence, the $\mathrm{Ni}-\mathrm{W}$ coating layer significantly decreased the corrosion current density of the $\mathrm{Cu}$ substrate by 1 order of magnitude. Consequently, the SSRT results completely corresponded to the polarization test results in the corrodkote environment. The aim of the work presented in this paper was to investigate the strain effect through the Ni-W coating layer in the corrodkote environment.
\end{abstract}

Keywords: Ni-W layer, slow strain rate testing (SSRT), corrodkote test, fracture surface

\section{$\underline{\text { FULL TEXT }}$}

(C) 2021 The Authors. Published by ESG (www.electrochemsci.org). This article is an open access article distributed under the terms and conditions of the Creative Commons Attribution license (http://creativecommons.org/licenses/by/4.0/). 